\title{
A Computational Fluid Dynamics Study in a PEM Fuel Cell with Different Flow Fields
}

\author{
C. E. Hernández-Herrera, S. J. Figueroa-Ramírez, H. Mandujano, L. Santis, J. M. Sierra* \\ Facultad de Ingeniería, Universidad Autónoma del Carmen. Cd. del Carmen, Campeche 62580, \\ México. \\ *E-mail: juanmsg@live.com.mx, jsierra@pampano.unacar.mx
}

doi: $10.20964 / 2020.12 .69$

Received: 3 August 2020 / Accepted: 19 September 2020 / Published: 31 October 2020

\begin{abstract}
In this paper, a computational fluid dynamics (CFD) study in a proton exchange membrane fuel cell model with different flow field designs is presented. The study was carried out to investigate the effects caused by serpentine, parallel, interdigitated and spiral channel configurations on the performance of fuel cells. An active area of $24 \mathrm{~cm} 2$ for all flow fields was considered. From a commercial CFD code that solves governing equations and an electrochemical model, local distributions of pressure, temperature, species, proton conductivity and current density contours were obtained. The numerical results were analyzed in detail and showed the contribution of each transport phenomenon to the electrochemical reactions that take place inside of the fuel cell. The simulations were carried out with operating conditions of a pressure of $3 \mathrm{~atm}$, a temperature of $353 \mathrm{~K}$ and a relative humidity of $100 \%$. The numerical results demonstrated that the spiral flow field is better than the other tested designs because it homogeneously distributes the species over the entire active area of the cell, which allows a better distribution of temperature and proton conductivity in the membrane and catalyst layer, respectively, favoring mass and energy transport through the fuel cell.
\end{abstract}

Keywords: PEM; Fuel cell; CFD; Flow Field.

\section{FULL TEXT}

(C) 2020 The Authors. Published by ESG (www.electrochemsci.org). This article is an open access article distributed under the terms and conditions of the Creative Commons Attribution license (http://creativecommons.org/licenses/by/4.0/). 